\title{
Correspondence
}

\section{Lord Sempill}

From Francis J. Boreham, Associate Fellow

$\mathrm{D}$ URING the period 1931-1935 I was Chief Inspector for National Flying Services, subsequently London Air Park Workshops, supervising repairs, C of A work and maintenance, when Colonel the Master of Sempill (as he then was) was our managing director. Flying his own Puss Moth, G-ABJU, he never missed an opportunity for advancing the cause of aviation and the private flyer, indeed very few meetings and air races of this period were missed by the "Col." and his well-known aircraft.

I remember many occasions, when I had the privilege of accompanying him on visits to the out stations, he invariably trimmed the monoplane very precisely, and was able to spend some time with reports and paperwork during the flight.

During the time he was director, many exciting events took place and he was largely responsible for the visit of the "Graf Zeppelin", RAeS Garden Party, visits of World flyers, and "Planette" pylon racing at London Air Park.

He really was a great pioneer, and thought nothing of setting off for Australia, in his Puss Moth. We fitted extra tanks, also an additional fuel tank on the luggage rack in the cabin, as we were concerned about him meeting strong head winds, over the Timor Sea. I still have a letter which he sent on arrival at Port Darwin, complimenting the workshop staff on the work done on his aeroplane which had given no trouble on the long journey. He always impressed me with his great enthusiasm for the work we were doing, also his keen understanding of people, and his charm, which stimulated and enabled things to be done better.

Truly a good man and distinguished pioneer, I remember him with affection, he gave me great help and encouragement in aviation.

The Editor regrets that this appreciation by $\mathrm{Mr}$. Boreham, which was received shortly after Lord Sempill's death, could not be included with Capt. Pritchard's "memoir" in the May JOURNAL.

\section{The Journal}

$\mathrm{T}$ HANK you for the splendid issue of the January JOURNAL. It projects a very real picture of events in the one hundred years of our history, and to me it recalls very vividly much that $I$ have been acquainted with, and lived with, since I became a boy-apprentice aero engine fitter with the RAF in 1925, leaving that excellent Service in 1951. I joined the Society in 1930.

What does the Journal mean to me? It keeps me informed upon the more important and interesting projects of which I might otherwise know little.

It has frequently focused attention upon the urgent need for the industry to become efficient, and to improve the quality and reliability of its products, a theme which pleases me, but which has as yet borne little fruit.

The colloquium on this subject was of particular interest and expresses many of the hopes and ideals of those who have been battling with aircraft serviceability problems over the years. Could not the Society publish these papers as a booklet and circulate it in quantity in all places where it might profitably be read? Surely some steps must be taken to get such a worth-while message across? (The work of the NCQR has certainly made those who work in industry conscious of the need for improvement in the quality and reliability of their products.)

It is probable that better guidance could be given by the publication of comprehensive statistics of unreliability in selective fields, indicating losses incurred and costs of rectification. It might then become apparent that the manufacturer must spend more on preventative measures, and further, the customer might find it expedient to share these extra costs.

It is apparent also that some new study might profitably be made of the payment and rewards to employees within the industry, tied in some way to quality and reliability. Throughout the war years the emphasis was undoubtedly upon quantity, and rewards and agreements were established towards this end. Has not the time come for management and workers to affect some re-appraisal of these issues?

Laurance Brown, Associate.

26th April 1966.

$T$ HE article by Mr. A. D. Baxter in the March JournaL was most interesting and having read the subsequent correspondence in the May issue, I am prompted, albeit a little late, to join in the discussion.

As a background, let me state that I am an undergraduate apprentice with the British Aircraft Corporation, reading Mechanical Sciences, to be followed by Economics, at Cambridge. Since my interests lie in the field of production management I am a student both of this Society and the Institution of Mechanical Engineers.

Please accept the following comments as the constructive criticism which they are intended to be.

The contrast between the JourNal and the "Chartered Mechanical Engineer" is little short of startling. Whilst the former has no editorial matter, reports of proceedings and a number of technical notes (which can only be of interest to quite a small proportion of members), the latter is eminently readable and deals not only with the practice of engineering "per se", but also with the education of engineers (surely of vital importance in view of our present losses to US-based industry) and the history of engineering. Certainly the publication of proceedings is important, so the Institution of Mechanical Engineers provides short precis of, and order forms for, copies of such reports, while publishing also the "Journal of Mechanical Engineering Science."

Obviously such a broad base is rendered more economic when the circulation is 66000 against our 12000 , but it seems to me that some arrangement of the JouRNAI mid-way between its present format and that of the CME would be possible, and would prove more popular with most members.

Whilst the Centenary JouRNAL was a splendid effort on which I should like to congratulate you, I feel that a more coherent arrangement would have made it even better.

It did stimulate me to organise, with the Engineering Dept. Librarian, an exhibition of the History of Aircraft in Britain, to be held in the Engineering Dept. in October. Many of the photographs to be used were kindly lent by the Royal Aeronautical Society Library to whom I am very grateful, and it seems to me that a survey of this nature, from your own files, would have made an excellent basis and background for the reminiscences in the Centenary JOURNAL. 